\title{
Moral values in the oral tradition of the BekesahPuspakrama text (a structural review)
}

\author{
Ahmad Turmuzi ${ }^{1}$, Emzir $^{2}$, Ninuk Lustiantie ${ }^{3}$ \\ \{ahmadturmuzi.unw@gmail.com ${ }^{1}$, emzir.pb@gmail.com², ninuk.lustyatie@unj.ac.id $\left.{ }^{3}\right\}$ \\ Universitas Nahdlatul Wathan Mataram, Indonesia ${ }^{1}$ \\ Universitas Negeri Jakarta, Indonesia ${ }^{2,3}$
}

\begin{abstract}
This study aims to obtain a detailed in-depth understanding of the moral values contained in the BekesahPusakrama text. This research is library research using a the LevisStrauss model of structural review with content analysis technique. The results reveal the concept of values related to 146 moral aspects. BekesahBuspakrama is a cultural heritage in a society, and this inherited tradition process forms a characteristic of oral tradition. Oral tradition of BekesahPuspakrama has a function as a system of protection of behavior and social control, while ritual activities are practical uses that are applied to the community as a philosophical position of BekesahPuspakrama. The implications of this research are expected to have an impact on the development of education, specifically on the preservation of the oral traditions as an effort to revitalize Indonesian language and literature.
\end{abstract}

Keywords: moral values, oral tradition, bekesahpuspakrama, structural review

\section{Introduction}

The movements and civilizations that humans traversed also left the writing tradition and oral traditions, proved to still exist, carried out by several community leaders and still preserved in some forms and types of oral activities in the process of ritual processes and offerings, customs processions, arts and performances as proof of inheritance from their ancestors. Issues that arise. Return to the view of 'about' native or 'authentic [1]. Language support and development are used as general information and preservation traditions [2]. A community and tradition in a community group cannot be intertwined with the traditions of other groups based on concepts and values in different customs as a form of the inheritance and relationship of its predecessor. This process of inheriting tradition continues as a part of oral tradition or folklore. Folklore is considered oral, partially oral folklore and folklore material. Oral folklore almost all of the material is oral and usually has a tradition of oral narrative [3].

Bekesah in Sasak language means telling stories, where the purpose is to explain moral values, educational values, historical values and life philosophy for Sasak people as individuals and humans in living their lives according to their environment. In addition, the oral tradition of Bekesah in Sasak community consists of prayer and hope, advice, struggle and heroism that have the meaning of local wisdom, universally this philosophy can be guided by the Indonesian people of Indonesia because there are several concepts of the same value even though indigenous tribes 
different, such as the values contained in the oral tradition texts BekesahPuspakrama. The oral tradition of the bekesahpuspakrama manuscript is also understood as text.

This study uses a structural approach. The main purpose of structural analysis is to dismantle and describe as thoroughly, as deeply as possible the interrelationships and intertwining of all aspects of literature together to produce a comprehensive meaning [4]The structure of the understanding is included in the content and form, [5]. Structural analysis cannot be separated from semiotic analysis. Because semiotics and structuralism are procedures for formalization and classification together. Both understand the whole culture as a communication system and sign system and work towards disclosure of binding rules [6]. The definition of structure and among them is a set of elements between which or between sub-ranks where relationships are expressed.

The main problem descriptions on the Puspakrama oral tradition text on the Sasak community should be understood and studied as part of knowledge, especially Indonesian language and literary education and other humanities. Research on the texts of the oral tradition of bekesah is actually a variety of ethnic and cultural in Indonesia. Is there a dormitory based on the relationships of meaning analysis based on the structural approach, the Levi-Strauss model.

\section{Literature Study}

\subsection{The Concept of Oral Tradition}

The Concept of Oral Tradition. A description of the basis of the history of oral tradition, especially in reviewing the history of traditions that existed and developed in the midst of society, the interesting thing is oral literature or oral tradition can also be transferred or transformed into written texts, especially in texts in the form of lontar. is a group of people who have physical, social and cultural identifying characteristics, so that they can be distinguished from other groups [7].

Folklore or oral tradition can be interpreted as identification of a group of people who have characteristics, social, and culture so that they can be distinguished from other social groups. These identifiers include, in the form of customs, forms of tradition, art, language, knowledge, and forms of belief or religion. Race is what is inherited by humans in their souls, the environment includes social conditions, while moments are social-political situations at certain times, [8].

It can be concluded that oral tradition is a cultural heritage of a society from the previous generation that still exists today; the inheritance becomes an identity in the community group. This oral tradition is written text which is written, oral and its expressions are spoken, and objects are revealed in the event custom and culture of the community. A tradition from culture is inherited from generation to generation, as a common property on the basis of identity awareness as well as a form of appreciation and preservation of cultural traditions in the community itself including oral literature and oral traditions.

\subsection{Forms and Types of Oral Traditions}


Forms and Types of Oral Traditions. Pure oral traditions in it are 1) people's language (Polk speech) such as accent, nickname, traditional rank and nobility, 2) expressions such as proverb, proverb, pemeo, 3) traditional statements (puzzles), 4) poetry people like pantun, gurindam and syair, 5) stories of folk prose such as myths, legends, and fables, and 6) caring for the people. The oral oral tradition is in the form of a mixture of oral and non-verbal elements. Included in this group are 1) traditional beliefs, 2) folk games, 3) customs, ceremonies, 4) folk theater, 5) people's parties [3].

Folk stories include folklore, myths, legends, beliefs, practices, superstitions, and so on. This highlights that the story of the people captures a wide range. It can even be said that folklore from a certain group of people is built according to their culture. People understand the world around them through the use of people's stories. Various superstitions, stories, beliefs all add to the creation of cultural heritage. The form of oral literature is certain (poetry, verse, gurindam, thimble, lyrical prose, which is in the form of prose called saga and the expression is called kilse [9]. Defined as saying that text is discourse (meaning oral) which is classified into written form [10].

\subsection{Values and Morals}

Values and Morals. Value is a measure for everything. Everything that lies before us has certain qualities and rules so that one thing is worth, while the other is not [11]. Moral refers to human behavior where morality is a practical activity and ethics describes theoretical, systematic reflection and rational for human behavior[12]. This means that the value is a standard and a measure of the nature, circumstances and abilities that are read and visible to someone through ways of thinking, how to behave, and actions. Value standards for each individual, group, there are differences based on mutual agreement.

\subsection{Structure of Manuscript BekesahPuspakrama}

Structure of Manuscript BekesahPuspakrama. Oral literature in that society has a function. First, it functions as a system of unconscious protection of society towards a dream such as the sangkuriang story. Second, it functions for the ratification of cultures such as origin stories. Third, serves as a means of enforcing social norms as a social control tool such as proverb. Fourth, it functions as a children's educational tool as told by the deer [3].

In Puspakrama workshops there are roles of the characters, names of places, times and problems that are contained as stories told, among others, (a). Raja Puspakrama, prince Jayangkasa, Mangkubumi, daughters, (b) the existence of KamasanBaitulmukdas, (c) goldsmiths, Ki kasian and Ni Kasian (d) Giants, demons and demons, (e), animals, animals, heirlooms or magical objects, eg bead, flying horse, golden fish, (f) the universe of the sky and slow.

Puspakrama is a mythical prose that tells about, (a) Moral values or good against evil, (b) this text tells the story of a very distant place, (c) a powerful spell and weapon, can go to the sky, (d) make inanimate things come alive, (e) good looks and morals produce goodness, (f) love and care for creatures as God commands, g) do not hurt the weak and not greedy, h) like to share and help others, i) banquet do not expect strings attached, (j) then the opening sentence begins with the opening word "Once upon a time". 


\section{Research Methods}

This study has the main objective, namely to obtain a deep and detailed understanding of; "Moral Values in the Oral Tradition of the Puspakrama Workshops (A Structure Review).

The oral tradition of the BekesahPuspakarma manuscript studied needs to pay attention to methods, technical approaches. The ritual activities in this study are not discussed. Because this research focuses on structural studies. The things that was discussed in this research methodology are things that are related to several important things such as research specific objectives, place and time of research, background of research, research methods, procedures for collecting data, recording data, analyzing data, checking data, checking the validity of data and the steps of research. Therefore, comprehensively starting from planning activities, implementation to the end of the research activities. The research data set can be accessed in osf.io Open Science Framework.

\section{Research Findings}

The description of this research process is the form of the results analysis as findings on moral values in the oral tradition of the manuscript BekesahPuspakrama based on a structural approach that is related to the structure of the story based on moral values that apply to the community where the manuscript is used and created. Based on the model used, namely Levis-Strauss, the researcher divides the elements that form the story into a relationship of events in the text that is told, and then analyzed. The discussion of moral values in the puspakrama literature is a focus and becomes a discussion of the findings in this study.

The BekesahPuspakram is a text used in traditional ritual ceremonies, unknown to the author, which consists of 533 song verses or paragraphs and 152 pages. The researcher conducts the observation, verification and identification of the manuscript. The researcher can carry out the analysis and interpretation process of the script with the findings of 230 verses containing moral values based on a structural approach of 54 song verses which are divided into (1) Blood and kinship relationships totaling 8 song statues, (2) Idealism relations and numbered countries 14 song verse, (3) Complication of mind, struggle and war are composed of 16 pieces of song, and (4) clarification and completion of 16 song verses. Based on the structural approach of the LevisStraus model with the terms and relations, where the model is rarely applied in the research of literary texts that use plot terms, or episodes in films.

\section{Discussion}

Manuscripts on the oral tradition of BekesahPuspakrama is a structure because it has a typography or series of stories in the text, then the sign system shows the meaning through the medium of language, namely the Jejawen language or the soft Sasak. The theory applied in the analysis is Levis-Strauss is a model of thinking relations, the relationship of the text with things 
that are mythological, relations or systematic relationships that build elements of the story with the plot or episode. Folk stories are stories that are organized around specific goals and themes, both to be linked to moral learning, to tell human truths, to describe war adventures and to tell stories of personality types and figures. In the previous explanation that structural analysis is an attempt to obtain deep and detailed meaning. Try to explain, outline the elements that build a series of stories or stories in the oral tradition manuscript BekesahPuspakrama, which relates the events told, according to the analysis of the structure used.

For the application of the structural analysis of the Levis-Strauss model, researchers can provide several examples and analyzes as follows:

\subsection{Relationship of Blood and Kinship}

Wenten cerita winarna, kacarita sira sang aji, Ing nagareng Puspakrama, ambakbala Ing budi, adil ing bala wargi, asih Ing kawula dusun, kawula pan mangkana, amuji Ing sri bupati, sawadyane tana kesel ing mana.

Meaning:

It is said that this is a story, the story of the prabu, in the state of Puspakrama, the mindset is very noble, it is fair to him, love to the rural people, the people are the same, always praising the King, all people are not upset, (PuhSinom 4)

It can be explained the quote above that, the relationship of blood and kinship that was conveyed at puhsinom 4 is the prabu, showing a family attitude not only limited to his own family, but the concept of the family is far wider, covering all the people from the hamlet to all the blood in his country, like the quote "Ingkawuladusun" this is a moral teaching about the nature of family and friendship for a leader.

\subsection{Analysis of idealism and state relations}

Wenten cerita winarna, kacarita sira sang aji, Ing nagareng Puspakrama, ambakbala Ing budi, adil ing bala wargi, asih Ing kawula dusun, kawula pan mangkana, amuji Ing sri bupati, sawadyane tana kesel ing manah

Meaning:

It is said that this is a story,the story of prabu, in the state of Puspakrama, the mindset Of his character is very noble, just to his heart, love to the rural people, the people are the same, always praising the King, all people are not hearted (puhsinom, 4).

It can be explained the quote above that, the relationship between idealism and the state was conveyed to (puhsinom, 4), said the prabu, in the State of Puspakrama fair in governing, the people loved him very much and were as exaggerated as the quote "amujilngsribupati", a moral teaching about leaders' attitudes and behaviors that are very important to emulate.

\subsection{Analysis of inner conflicts; opposition and struggle}


Karsanya sarwa ulam, mwah sasangan sami, korana reke mangkana, manawi reke larakena. Ya ta sri narapati, amiyarsa warta iku, yenana wong kamasan, lewih kawisanireki, apapande kancana dadi iwak

Meaning:

Wanting that all fish, and all food (imitated), because of that, so as not to be persecuted, the King Puspakrama, hearing the news, about the existence of the Kamasan people, had become famous in intelligence, forging gold into fish (puhsinom 6)

Can be explained the above quote that, inner complications, opposition and struggle in the text of the text Bekesahpuspakrama delivered to (puhsinom: 6) the inner complication is reflected in the attitude of the Raja puspakrama to make toys for his four-year-old child, such as "Karsanyasarwaulam, mwah sasangansami, koranarekemangkana, manawirekelarakena ". This is a form of inner complication in the figure of Raja puspakrama presented in the manuscript.

\subsection{Analysis of clarification and settlement}

It can be explained that the clarification and resolution of the events of stories that occur in blood relations and kinship, idealism and state relations, as well as inner complications, conflicts and struggles that occur in leaders and characters in oral tradition texts BekesahPuspakrama, by solving problems from complications. - The compilation, among others, is explained as follows:

Pernahe Kamasan ika, ing Betalmukdas rekeki, dan sang nata puspakrama, pangalasan den dutani, datengi sri bupati, ing betalmukdas puniku, tan kawarna ing marga, pangalasan sampun prapti, ing negara betalmukdas punika

Meaning:

The Kamasan place, in the land of Betalmukdas, and the King of the Puspakrama, sent Court messengers, to the Regent, In Betalmukdas, inseparable in the trip, the messenger had arrived, in the land of Betalmukdas (Puhsinom, 7).

It can be seen that the settlement of the King's inner conflict in Puspakrama was due to his great affection for his son so the King sent an envoy to meet the goldsmith to the land of Betalmukdas to make gold fish as toys for his son, as in the quote above (Puhsinom, 7).

\section{Conclusions and Suggestions}

That oral tradition is a cultural inheritance of a society from the previous generation that still exists today, the inheritance becomes the identity of the community group. This oral tradition is written text which is written, oral and the expressions are spoken, and the objects are revealed in the customary events and community culture. Likewise in the sasak community, oral traditions are 
still carried out in a number of religious ceremonies and rituals, such as in rituals with the media of the bekesah manuscript.

Bekesah itself in Sasak language means telling stories, where the purpose is to explain moral values, educational values, historical values and life philosophy for Sasak people as individuals and humans in living their lives according to their environment. In addition, the oral tradition of Bekesah in the Sasak community consists of prayer and hope, advice, struggle and heroism that have the meaning of local wisdom, universally this philosophy can be guided by the Indonesian people of Indonesia because there are several concepts of the same value even though indigenous tribes different, such as the values contained in the oral tradition texts BekesahPuspakrama.

The Manuscript for Preservation of Puspakrama in the Sasak community is still seen only in the spiritual area. Not only in the BekesahPuspakrma text, oral traditions in Bekesah manuscripts are also found in other lontar manuscripts and develop in the midst of Sasak people's lives. Creative whose object is man and his life, using language as his medium.

Suggestions and author recommendations, to: 1) Teachers, especially teaching the text of the text of the Examination is very useful in the world of education in schools and in universities, especially the Faculty of Letters and Indonesian and regional education study programs. 2) West Nusa Tenggara Regional Government, 3) Artists, Culturemen, and Researchers as well as interested parties such as Artists and cultural experts, as well as researchers with problems in the study of oral traditions, especially the oral traditions of the Sasak people, should revitalize and

raise Bekesah in texts that similar to the manuscript BekesahPuspakrama for the development of knowledge and good character building in the community.

\section{Reference}

[1] K. Dobransky, "City folk: Survival strategies of tradition-bearing organizations," Poetics, vol. 35, pp. 239-261, 2007.

[2] M. Sheridan, et al., "Gaelic singing and oral tradition," International Journal of Music Education, vol. 29, pp. 172-190, 2011.

[3] E. Emzir and S. Rohman, "Teori dan pengajaran sastra," Jakarta: Raja Grafindo Persada, 2015.

[4] A. Rokhmansyah, Studi dan pengkajian sastra: perkenalan awal terhadap ilmu sastra: Graha Ilmu, 2014.

[5] R. Wellek and A. Warren, Theory of literature: Harcourt, Brace \& World New York, 1956.

[6] R. D. Pradopo, "Pengkajian Puisi: Analisis Strata Norma dan Analisis Struktual dan Semiotik," ed: Yogyakarta: Gajah Mada University Press, 2010.

[7] J. Danandjaja, et al., Folklor Amerika: cermin multikultural yang manunggal: Pustaka Utama Grafiti, 2003.

[8] K. Yudiono, Pengantar sejarah sastra Indonesia: Grasindo, 2010.

[9] A. Amir, "Keefektifan Kalimat dalam Makalah Mahasiswa Nonreguler Pendidikan Bahasa Dan Sastra Indonesia FKIP Untan," Jurnal Visi Ilmu Pendidikan, vol. 5, pp. 445-478, 2011.

[10] S. A. Devik, et al., "'Picking up the pieces"-Meanings of receiving home nursing care when being old and living with advanced cancer in a rural area," International journal of qualitative studies on health and well-being, vol. 10, p. 28382, 2015.

[11] A. Rohman, Memahami Ilmu Pendidikan: CV. Aswaja Pressindo, 2013. 
[12] M. A. Choudhury, "Religion and social economics (a systemic theory of organic unity)," International Journal of Social Economics, vol. 43, pp. 134-160, 2016. 